\title{
Biology and clinical utilization of mesenchymal progenitor cells
}

\section{J.J. Minguell1,2, \\ P. Conget ${ }^{1}$ \\ and A. Erices ${ }^{1}$}

\author{
${ }^{1}$ Laboratorio de Biología Celular, INTA, Universidad de Chile, and \\ ${ }^{2}$ Laboratorio de Transplante de M édula Ó sea, Clínica Las Condes, Santiago, Chile
}

\begin{abstract}
Correspondence
J.J. Minguell

Laboratorio de Biología Celular

INTA, Universidad de Chile

Casilla 138-11

Santiago

Chile

Fax: + 56-2-221-4030

E-mail: jminguell@uec.inta.uchile.cl

Research supported in part by Fondecyt (Chile) to J.J. Minguell (No. 8970028), to P. Conget (No. 2970016) and to A. Erices (No. 2980017), and International Center for Genetic Engeneering and Biotechnology to J.J. Minguell (No. CRP/CHI97-01 (a1)). P. Conget and $A$. Erices are recipients of doctoral fellowships from Fundación Andes and Conicyt, respectively.
\end{abstract}

Received April 3, 2000 Accepted May 3, 2000

\section{Abstract}

Within the complex cellular arrangement found in the bone marrow stroma there exists a subset of nonhematopoietic cells referred to as mesenchymal progenitor cells (MPC). These cells can be expanded ex vivo and induced, either in vitro or in vivo, to terminally differentiate into at least seven types of cells: osteocytes, chondrocytes, adipocytes, tenocytes, myotubes, astrocytes and hematopoietic-supporting stroma. This broad multipotentiality, the feasibility to obtain MPC from bone marrow, cord and peripheral blood and their transplantability support the impact that the use of MPC will have in clinical settings. However, a number of fundamental questions about the cellular and molecular biology of MPC still need to be resolved before these cells can be used for safe and effective cell and gene therapies intended to replace, repair or enhance the physiological function of the mesenchymal and/ or hematopoietic systems.

\section{Origin of the concept of bone marrow-derived mesenchymal progenitors}

The work initiated by Friedenstein and collaborators (1) provided definitive evidence that bone marrow contains, in addition to the hematopoietic progenitors, a population of spindle-shaped clonogenic fibroblast precursor cells or fibroblast colony-forming units (CFU-F). These cells, which were defined in vivo as quiescent resting cells, after proper in vitro stimulation can enter the cell cycle and develop colonies that resemble small deposits of bone or cartilage (2). Since CFU-F exhibit a high ability for self-renewal and multipotentiality, it was speculated that these "marrow stromal stem cells" were the pre-

\section{Key words}

- Mesenchymal progenitor cells

- Transplantation

- Differentiation cursors of a number of different mesenchymal cell lineages $(3,4)$. Thus, the concept that the marrow stromal moiety was part of a wider stromal mesenchymal system in adult organisms was developed.

Data related to the number and hierarchy of cell lineages belonging to the stromal mesenchymal system, in addition to a substantial progress in the understanding of the differentiation process and the characterization of the evolving phenotypes, open perspectives for the use of these "marrow stromal stem cells" in cellular or genetic therapies for mesenchymal disorders $(5,6)$. In this review we will highlight in a rather selective manner the current knowledge on this stromal mesenchymal system.

The term CFU-F or marrow stromal fi- 
broblasts (7) has been gradually abandoned and replaced by diverse, still indistinct denominations, like marrow stromal cells (5), mesenchymal stem cells (4), or mesenchymal progenitor cells (MPC) (8). Nevertheless, in all cases reference is made to a particular adherent cell type evolving from bone marrow-derived low density mononuclear cells, cultured in a classical medium supplemented only with selected batches of fetal bovine serum. Cells thus developed, which hereafter will be referred to as MPC, display a fibroblast-like morphology, can be expanded ex vivo and present a potential to terminally differentiate into at least seven types of cells: osteocytes, chondrocytes, adipocytes, tenocytes, myotubes, astrocytes and hematopoietic-supporting stroma (7,9-16). We should emphasize that the denomination "marrow stromal cells" has also been used for monolayers of longterm marrow stroma or Dexter-type cultures (17). However, culture conditions, evolving phenotypes, differentiation potential and secretion products of the above cells are not analogous to those of MPC, but are in fact quite dissimilar $(18,19)$.

\section{Characteristics of MPC}

Human MPC cultures contain a homogenous population of fibroblast-like cells which have a population doubling time of $33 \mathrm{~h}$ and exhibit a large (20) but variable ex vivo expansive potential. It has been reported that while some MPC preparations can be expanded over 15 cell doublings, others cease replicating after about 4 cell doublings (21-23). In addition, as samples are highly expanded, MPC apparently lose their multipotentiality and approach senescence and/or express apoptotic features $(20,22)$.

Cell cycle studies on human MPC cultures have revealed the presence of a fraction $(20 \%)$ of cells with a quantitative pattern of RNA and DNA typical of quiescent
(G0) cells (20). These cells can be isolated by a negative selection procedure using 5fluorouracil, which originates a population of more than $90 \%$ G0 cells, expressing the gene for ornithine decarboxylase antizyme, a marker for cellular unproliferative status. The resting condition, together with a selective immunophenotype and the absence of the expression of commitment markers in the selected cells, suggest that within cultures of MPC a fraction of mesenchymal stem-like cells subsists (Conget $P$, unpublished results). This finding gives experimental support to the hypothesis that a "rare" mesenchymal stem cell in the bone marrow is capable of self-renewal and differentiation into various mesenchymal lineages.

The antigenic phenotype of MPC is not unique, borrowing features of mesenchymal, endothelial, epithelial and muscle cells $(9,14,20,24)$. Since MPC do not express typical hematopoietic lineage markers (CD14, CD34, CD45) $(9,20)$, it has been postulated that bone marrow hosts at least two main different stem/progenitor cells which can give rise to mature hematopoietic and mesenchymal cells $(5,25)$.

The extended cytokine expression profile of MPC, which includes several hematopoietic and nonhematopoietic growth factors, interleukins and chemokines $(18,26)$, suggests that MPC contribute to the marrow microenvironment with inductive/regulatory signals for the development of hematopoietic cells as well as for stromal cells, including the MPC itself. The latter is sustained by recent data showing that MPC express numerous growth factor and cytokine receptors (9, and Erices A, unpublished results), suggesting that the function of these cells is under the control of autocrine or juxtacrine loops. Additional evidence for the dynamic function performed by MPC in the marrow microenvironment is given by data revealing their capacity to produce and organize a vast array of extracellular matrix molecules (19). Moreover, MPC express several counterre- 
ceptors associated with matrix- and cell-tocell adhesive interactions $(9,20)$.

\section{Differentiation potential of MPC}

One of the first descriptions of the in vivo differentiation potential of MPC was the report showing that after a successful and uneventful HLA-matched marrow allograft, a dog suddenly died of respiratory failure due to extensive ossification of the lungs with multiple sites of hematopoietic engraftment (27). This study, described by the authors as "an unexpected phenomenon", was followed by several studies showing that in animal models, cultured MPC once transplanted can develop into terminally differentiated mesenchymal tissues, like bone $(7,10$, 28-30), cartilage $(10,29,31)$, tendon $(13,32)$, muscle (33), neural (16) or hematopoietic microenvironments (7). The given examples just reaffirm the broad multipotentiality of MPC, probably the adult stem/progenitor cell exhibiting the highest degree of plasticity $(6,34)$.

Most of the studies on the in vitro differentiation potential of MPC, mainly into osteoblasts, chondrocytes, myotubes and hematopoietic-supporting stroma, came from the work by Caplan and colleagues $(4,11,15,35)$. These studies have provided information regarding culture conditions, proper stimuli and methods for identification of the respective ultimate differentiated phenotype.

The molecular and cellular events associated with differentiation pathways are not well understood, but it seems that the commitment to the osteo-chondrogenic or adipogenic lineages requires the expression of Cbfa-1 or PPAR $\gamma 2$, respectively $(36,37)$. Subsequent maturation along these pathways includes the expression of alkaline phosphatase, osteopontin, osteocalcin and collagen I in the osteocytic lineage; collagen II and IX in the chondrocytic lineage, and aP2, adipsin, leptin and lipoprotein lipase in the adipocytic one $(9,38)$. Thus, analyses at the gene expression level (RT-PCR) have shown that MPC differentiate in vitro, according to the stimuli applied, into the desired lineage but not into cells expressing multiple lineages (9).

Although diagrams for a hierarchy of MPC progenitors evolving from a putative mesenchymal stem cell have been published $(6,39)$, data explaining how lineage choices and transcriptional specificities are achieved and how these account for the extraordinary multipotency of mesenchymal progenitor cells are lacking. It will be challenging for investigators in the field to fill in the gaps on these issues.

\section{Sources of MPC}

Recent data have shown that, in addition to adult bone marrow, umbilical cord blood is also a source of MPC (40). These cells exhibit an immunophenotype, a population of quiescent cells and a differentiation potential similar to that of marrow-derived MPC. The observation that the content of MPC is higher in preterm than in term cord blood, a trend also observed for hematopoietic progenitors (41), suggests that hematopoietic and mesenchymal progenitors travel early during development, probably from fetal hematopoietic sites to the newly formed bone marrow via cord blood (42).

Whether MPC circulate in peripheral blood is an open issue. In the murine model, CFU-F circulate in blood and represent a stromal cell population which can migrate into hematopoietic organs (43). In humans, cells with the characteristics of mesenchymal progenitors were detected in growth factor-mobilized peripheral blood stem cells harvested from breast cancer patients, but not in the blood from normal donors (44). However, under similar but not identical experimental conditions, the presence of circulating MPC has not been confirmed by other groups $(45,46)$. 


\section{Transplantation of MPC}

The envisioned routes of MPC delivery are either direct loading (injection or implants) into the damaged organ or systemic infusion. In the former case, it has been proposed that MPC will augment local repair or regeneration of bone (28-30), cartilage (47) or tendon (32). With respect to systemic infusion, MPC should home into the damaged tissue and restart their developmental program. Thus, MPC will improve target tissue function $(48,33)$ or increase marrow microenvironment support to facilitate engraftment by hematopoietic stem cells $(6,49)$.

Despite the profuse information on the origin (host or donor) of stromal cells after allogeneic transplantation, the issue is still open because of contradictory data. Thus, it has been reported that after successful allogeneic bone marrow transplantation (considered as a source of hematopoietic and mesenchymal progenitors), MPC isolated at different time intervals after transplantation exhibit cellular and molecular features that correspond either to the host (50-52) or to the donor $(48,53,54)$. The nature of this conflict may arise from several determinants, among them the methods used to type MPC, the procedure followed to harvest the marrow $(21,55)$, the low frequency of MPC in marrow harvests (2-5 MPC per $1 \times 10^{6}$ mononuclear cells) (50), and/or the condition (steady state $v s$ post chemo- or radiotherapy) of the marrow from which MPC were prepared $(22,52)$ and to which MPC were transplanted.

An additional explanation for the discrepancy about the marrow transplantation capacity of MPC may arise from the observation that the number of mesenchymal stemlike cells among different cultures is low and variable (20, and Conget $P$, unpublished results). Based on data for the hematopoietic and muscle system $(56,57)$, one can speculate that quiescent and cycling MPC present in the graft will contribute in a different way to stromal repopulation after transplantation. Mesenchymal stem-like cells, after homing to the marrow space will self-renew and thereby sustain long-term mesengenesis. In turn, cycling MPC which will probably also home to other mesenchymal tissues due to their committed condition, will only contribute to short-term mesengenesis. Whatever the case, there are still many open questions concerning the transplantability of MPC, either as isolated cells, after ex vivo expansion, or as whole cells with hematopoietic progenitors (55).

\section{Clinical trials using M PC}

Given the promising features of adult stem cells for the development of new cell therapies $(6,34)$, researchers in the field of MPC have pursued a broad range of lines of investigation to stimulate their therapeutic utilization.

The first clinical trials reported have revealed that systemic infusion of ex vivo expanded autologous MPC is feasible and safe in the short-term $(49,58)$. However, there is yet no conclusive evidence to support the contention that transplanted MPC may have a positive impact on the management of lymphohematopoietic or cancer patients (49). On the other hand, it has been demonstrated that allogeneic bone marrow transplantation in children with osteogenesis imperfecta results in impressive histological changes in trabecular bone which indicate new dense bone formation (59). In addition, increased growth rate and reduced frequencies of bone fracture were also observed. These changes, detected 3 months after marrow transplantation, were associated with the engraftment of functional MPC from the transplanted marrow (25). Surprisingly, recent reports have documented that following bone marrow transplantation, short-term changes in bone mineral metabolism caused a rapid impairment of bone formation and an increase in bone resorption (60). 


\section{Conclusions and future directions}

The last five years have been the scene of a substantial improvement in our understanding of the biology and the potential clinical utilization of adult MPC. Although many aspects related to the properties of these cells are well established, information dealing with the existence of a hierarchy of mesenchymal precursors (including the mesenchymal stem cell itself) and their properties still remains obscure. However, this lack of information has not been an obstacle in terms of the therapeutic utilization of these cells.

MPC represent an attractive therapeutic option, both in the context of cellular and gene therapy strategies for a wide range of clinical applications. Future clinical trials should be focused on at least two main issues: as an integral part of the marrow microenvironment, MPC transplantation alone or in conjunction with hematopoietic progenitors would facilitate the engraftment of the hematopoietic stem cell after myeloablative therapy. Also, they might replace chemotherapy- or disease associated-damaged stroma or modulate graft versus host disease; transplantation of MPC, as precursors of several mesenchymal lineages, is envi- sioned as the proper therapy to attenuate or correct disorders of mesenchymal tissues, like osteogenesis imperfecta, osteoporosis, osteoarthrosis, meniscectomy, muscular dystrophy, etc.

To improve the latter, several studies have shown the feasibility of adeno- or retroviral-mediated gene transfer of reporter or therapeutic genes into MPC $(8,61,62)$. For the near future, we anticipate a rapid closure of many gaps in our knowledge of the biology of MPC, which may facilitate the development of phase II and III clinical trials for new therapeutic alternatives using MPC. Thus, as recently proposed, MPC are "no longer second class marrow citizens" as compared with hematopoietic progenitors, the paradigm of bone marrow cells (25).

\section{Acknowledgments}

We are grateful to Dr. Radovan Borojevic (Universidade Federal do Rio de Janeiro, Rio de Janeiro, RJ, Brazil) for helpful discussions. We also thank Drs. Cecilia Rojas and Tomás Walter (Universidad de Chile, Santiago, Chile) for a critical review of the manuscript.

\section{References}

1. Friedenstein A , Gorskaja J F \& Kulagina NN (1976). Fibroblast precursors in normal and irradiated mouse hematopoietic organs. Experimental Hematology, 4: 267274.

2. Castro-Malaspina H, Gay RE, Resnick G, Kapoor N, Meyers P, Chiarieri D, McKenzie S, Broxmeyer HE \& Moore MA (1980). Characterization of human bone marrow fibroblast colony-forming cells (CFU-F) and their progeny. Blood, 56: 289301.

3. Owen M (1988). Marrow stromal stem cells. J ournal of Cell Science (Suppl), 10: 63-76.

4. Caplan Al (1994). The mesengenic process. Clinics in Plastic Surgery, 21: 429435.
5. Prockop DJ (1997). Marrow stromal cells as stem cells for nonhematopoietic tissues. Science, 276: 71-74.

6. Bordignon C, Carlo-Stella C, Colombo MP, De Vincentiis A, Lanata L, Lemoli RM, Locatelli F, Olivieri A, Rondelli D, Zanon P \& Tura S (1999). Cell therapy: achievements and perspectives. Haematologica, 84: 1110-1149.

7. Kuznetsov SA, Friedenstein AJ \& Robey PG (1997). Factors required for bone marrow fibroblast colony formation in vitro. British J ournal of Haematology, 97: 561570.

8. Conget P \& Minguell JJ (2000). Adenoviral-mediated gene transfer into ex vivo expanded human bone marrow mesenchymal progenitor cells. Experimental He- matology, 28: 382-390.

9. Pittenger MF, Mackay AM, Beck SC J aiswal RK, Douglas R, Mosca J D, Moorman MA, Simonetti DW, Craig S \& Marshak DR (1999). Multilineage potential of adult human mesenchymal stem cells. Science, 284: 143-147.

10. Pereira RF, Halford KW, O'Hara MD, Leeper DB, Sokolov BP, Pollard MD, Bagasra O \& Prockop DJ (1995). Cultured adherent cells from marrow can serve as long-lasting precursor cells for bone, cartilage, and lung in irradiated mice. Proceedings of the National Academy of Sciences, USA, 92: 4857-4861.

11. Dennis J E, Merriam A, Awadallah A, Yoo J U, J ohnstone B \& Caplan Al (1999). A quadripotential mesenchymal progenitor 
cell isolated from the marrow of an adult mouse. J ournal of Bone and Mineral Research, 14: 700-709.

12. Beresford J N, Bennett J H, Devlin C, Leboy PS \& Owen ME (1992). Evidence for an inverse relationship between the differentiation of adipocytic and osteogenic cells in rat marrow stromal cell cultures. J ournal of Cell Science, 102: 341351.

13. Awad HA, Butler DL, Boivin GP, Smith FN, Malaviya P, Huibregtse B \& Caplan AI (1999). Autologous mesenchymal stem cell-mediated repair of tendon. Tissue Engineering, 5: 267-277.

14. Galmiche MC, Koteliansky VE, Briere J, Herve P \& Charbord P (1993). Stromal cells from human long-term marrow cultures are mesenchymal cells that differentiate following a vascular smooth muscle differentiation pathway. Blood, 82: 66-76.

15. Wakitani S, Saito T \& Caplan Al (1995). Myogenic cells derived from rat bone marrow mesenchymal stem cells exposed to 5-azacytidine. Muscle and Nerve, 18: 1417-1426.

16. Kopen GC, Prockop DJ \& Phinney DG (1999). Marrow stromal cells migrate throughout forebrain and cerebellum, and they differentiate into astrocytes after injection into neonatal mouse brains. Proceedings of the National Academy of Sciences, USA, 96: 10711-10716.

17. Gartner S \& Kaplan HS (1980). Long-term culture of human bone marrow cells. Proceedings of the National Academy of Sciences, USA, 77: 4756-4759.

18. Majumdar MK, Thiede MA, Mosca JD, Moorman M \& Gerson SL (1998). Phenotypic and functional comparison of cultures of marrow-derived mesenchymal stem cells (MPCs) and stromal cells. J ournal of Cellular Physiology, 176: 57-66.

19. Chichester CO, Fernandez $M$ \& Minguell JJ (1993). Extracellular matrix gene expression by human bone marrow stroma and by marrow fibroblasts. Cell Adhesion and Communication, 1: 93-99.

20. Conget PA \& Minguell J J (1999). Phenotypical and functional properties of human bone marrow mesenchymal progenitor cells. J ournal of Cellular Physiology, 181: 67-73.

21. Phinney DG, Kopen G, Righter W, Webster S, Tremain N \& Prockop DJ (1999). Donor variation in the growth properties and osteogenic potential of human marrow stromal cells. J ournal of Cellular Biochemistry, 75: 424-436.

22. Digirolamo CM, Stokes D, Colter D,
Phinney DG, Class R \& Prockop DJ (1999). Propagation and senescence of human marrow stromal cells in culture: a simple colony-forming assay identifies samples with the greatest potential to propagate and differentiate. British J ournal of Haematology, 107: 275-281.

23. Bruder SP, J aiswal N \& Haynesworth SE (1997). Growth kinetics, self-renewal, and the osteogenic potential of purified human mesenchymal stem cells during extensive subcultivation and following cryopreservation. J ournal of Cellular Biochemistry, 64: 278-294.

24. Haynesworth SE, Baber MA \& Caplan AI (1992). Cell surface antigens on human marrow-derived mesenchymal cells are detected by monoclonal antibodies. Bone, 13: 69-80.

25. Gerson SL (1999). Mesenchymal stem cells: no longer second class marrow citizens. Nature Medicine, 5: 262-263.

26. Haynesworth SE, Baber MA \& Caplan Al (1996). Cytokine expression by human marrow-derived mesenchymal progenitor cells in vitro: effects of dexamethasone and IL-1 alpha. J ournal of Cellular Physiology, 166: 585-592.

27. Sale GE \& Storb R (1983). Bilateral diffuse pulmonary ectopic ossification after marrow allograft in a dog. Evidence for allotransplantation of hemopoietic and mesenchymal stem cells. Experimental Hematology, 11: 961-966.

28. Richards $M$, Huibregtse BA, Caplan Al, Goulet J A \& Goldstein SA (1999). Marrow-derived progenitor cell injections enhance new bone formation during distraction. J ournal of Orthopaedic Research, 17: 900-908.

29. Kadiyala S, Young RG, Thiede MA \& Bruder SP (1997). Culture expanded canine mesenchymal stem cells possess osteochondrogenic potential in vivo and in vitro. Cell Transplantation, 6: 125-134.

30. Goshima J, Goldberg VM \& Caplan Al (1991). The origin of bone formed in composite grafts of porous calcium phosphate ceramic loaded with marrow cells. Clinical Orthopaedics and Related Research, 269: 274-283.

31. Kataoka H \& Urist MR (1993). Transplant of bone marrow and muscle-derived connective tissue cultures in diffusion chambers for bioassay of bone marrow morphogenetic protein. Clinical Orthopaedics and Related Research, 286: 262-270.

32. Young RG, Butler DL, Weber W, Caplan Al, Gordon SL \& Fink DJ (1998). Use of mesenchymal stem cells in a collagen matrix for Achilles tendon repair. J ournal of Orthopaedic Research, 16: 406-413.

33. Ferrari G, Cusella-De Angelis G, Coletta M, Paolucci E, Stornaiuolo A, Cossu G \& Mavilio $F$ (1998). Muscle regeneration by bone marrow-derived myogenic progenitors. Science, 279: 1528-1530.

34. Weissman IL (2000). Translating stem and progenitor cell biology to the clinic: barriers and opportunities. Science, 287: 14421446.

35. J aiswal N, Haynesworth SE, Caplan AI \& Bruder SP (1997). Osteogenic differentiation of purified, culture-expanded human mesenchymal stem cells in vitro. J oumal of Cellular Biochemistry, 64: 295-312.

36. Ducy P, Zhang R, Geoffroy V, Ridall AL \& Karsenty G (1997). Osf2/Cbfal: a transcriptional activator of osteoblast differentiation. Cell, 89: 743-754.

37. Tontonoz $\mathrm{P}, \mathrm{Hu} E$ \& Spiegelman BM (1994). Stimulation of adipogenesis in fibroblasts by PPAR gamma 2, a lipid-activated transcription factor. Cell, 79: 11471156

38. Gori F, Thomas T, Hicok KC, Spelsberg TC \& Riggs BL (1999). Differentiation of human marrow stromal precursor cells: bone morphogenetic protein-2 increases OSF2/CBFA1, enhances osteoblast commitment, and inhibits late adipocyte maturation. J ournal of Bone and Mineral Research, 14: 1522-1535.

39. Bruder SP, Horowitz MC, Mosca JD \& Haynesworth SE (1997). Monoclonal antibodies reactive with human osteogenic cell surface antigens. Bone, 21: 225-235.

40. Erices A, Conget P\& Minguell J J (2000). Mesenchymal progenitor cells in human umbilical cord blood. British J ournal of Haematology (in press).

41. Shields LE \& Andrews RG (1998). Gestational age changes in circulating CD34+ hematopoietic stem/progenitor cells in fetal cord blood. American J ournal of Obstetrics and Gynecology, 178: 931-937.

42. Tavassoli M (1991). Embryonic and fetal hemopoiesis: an overview. Blood Cells, 1: 269-281.

43. Piersma AH, Ploemacher RE \& Brockbank KG (1983). Transplantation of bone marrow fibroblastoid stromal cells in mice via the intravenous route. British J ournal of Haematology, 54: 285-290.

44. Fernandez M, Simon V, Herrera G, Cao C, Del Favero H \& Minguell JJ (1997). Detection of stromal cells in peripheral blood progenitor cell collections from breast cancer patients. Bone Marrow Transplantation, 20: 265-271.

45. Lazarus HM, Haynesworth SE, Gerson SL $\&$ Caplan Al (1997). Human bone marrow- 
derived mesenchymal (stromal) progenitor cells (MPCs) cannot be recovered from peripheral blood progenitor cell collections. J ournal of Hematotherapy, 6: 447455.

46. Ojeda-Uribe $M$, Brunot $A$, Lenat $A \&$ Legros M (1993). Failure to detect spindleshaped fibroblastoid cell progenitors in PBPC collections. Acta Haematologica, 90: 139-143.

47. J ohnstone B \& Yoo JU (1999). Autologous mesenchymal progenitor cells in articular cartilage repair. Clinical Orthopaedics and Related Research, 367 (Suppl): S156-S162.

48. Pereira RF, O'Hara MD, Laptev AV, Halford KW, Pollard MD, Class R, Simon D, Livezey K \& Prockop DJ (1998). Marrow stromal cells as a source of progenitor cells for nonhematopoietic tissues in transgenic mice with a phenotype of osteogenesis imperfecta. Proceedings of the National Academy of Sciences, USA, 95: 1142-1147.

49. Koc ON, Gerson SL, Cooper BW, Dyhouse SM, Haynesworth SE, Caplan AI \& Lazarus HM (2000). Rapid hematopoietic recovery after coinfusion of autologousblood stem cells and culture-expanded marrow mesenchymal stem cells in advanced breast cancer patients receiving high-dose chemotherapy. J ournal of Clinical Oncology, 18: 307-316.

50. Koc ON, Peters C, Aubourg P, Raghavan S, Dyhouse S, DeGasperi R, Kolodny EH, Yoseph YB, Gerson SL, Lazarus HM, Caplan Al, Watkins PA \& Krivit W (1999). Bone marrow-derived mesenchymal stem cells remain host-derived despite successful hematopoietic engraftment after allogeneic transplantation in patients with lysosomal and peroxisomal storage dis- eases. Experimental Hematology, 27: 1675-1681.

51. Simmonds PJ , Przepiorka ED, Thomas ED \& Torok-Storb B (1987). Host origin of marrow stromal cells following allogeneic bone marrow transplantation. Nature, 328: 429-432.

52. Galotto $M$, Berisso $G$, Delfino $L$, Podesta $M$, Ottaggio $L$, Dallorso $S$, Dufour $C$, Ferrara GB, Abbondandolo A, Dini G, Bacigalupo A, Cancedda R \& Quarto R (1999). Stromal damage as consequence of high-dose chemo/radiotherapy in bone marrow transplant recipients. Experimental Hematology, 27: 1460-1466.

53. Almeida-Porada G, Flake AW, Glimp HA \& Zanjani ED (1999). Cotransplantation of stroma results in enhancement of engraftment and early expression of donor hematopoietic stem cells in utero. Experimental Hematology, 27: 1569-1575.

54. Keating A, Singer J W, Killen PD, Striker GE, Salo AC, Sanders J, Thomas ED, Thorning D \& Fialkow PJ (1982). Donor origin of the in vitro haematopoietic microenvironment after marrow transplantation in man. Nature, 298: 280-283.

55. Blazsek I, Delmas Marsalet B, Legras S, Marion S, Machover $D \&$ \& Misset $J \mathrm{~L}$ (1999). Large scale recovery and characterization of stromal cell-associated primitive haemopoietic progenitor cells from filter-retained human bone marrow. Bone Marrow Transplantation, 23: 647-657.

56. Gothot A, van der Loo J C, Clapp DW \& Srour EF (1998). Cell cycle-related changes in repopulating capacity of human mobilized peripheral blood CD34(+) cells in non-obese diabetic/severe combined immune-deficient mice. Blood, 92: 2641-2649.

57. Beauchamp J R, Morgan J E, Pagel CN \&
Partridge TA (1999). Dynamics of myoblast transplantation reveal a discrete minority of precursors with stem cell-like properties as the myogenic source. J ournal of Cell Biology, 144: 1113-1122.

58. Lazarus HM, Haynesworth SE, Gerson SL, Rosenthal NS \& Caplan AI (1995). Ex vivo expansion and subsequent infusion of human bone marrow-derived stromal progenitor cells (mesenchymal progenitor cells): implications for therapeutic use. Bone Marrow Transplantation, 16: 557564.

59. Horwitz EM, Prockop DJ, Fitzpatrick LA, Koo WW, Gordon PL, Neel M, Sussman $M$, Orchard P, Marx J C, Pyeritz RE \& Brenner MK (1999). Transplantability and therapeutic effects of bone marrow-derived mesenchymal cells in children with osteogenesis imperfecta. Nature Medicine, 5: 309-313.

60. Kang MI, Lee WY, Oh KW, Han J H, Song $\mathrm{KH}$, Cha BY, Lee KW, Son HY, Kang SK \& Kim CC (2000). The short-term changes of bone mineral metabolism following bone marrow transplantation. Bone, 26 : 275-279.

61. Marx J C, Allay J A, Persons DA, Nooner SA, Hargrove PW, Kelly PF, Vanin EF \& Horwitz EM (1999). High-efficiency transduction and long-term gene expression with a murine stem cell retroviral vector encoding the green fluorescent protein in human marrow stromal cells. Human Gene Therapy, 10: 1163-1173.

62. Lou J , Xu F, Merkel K \& Manske P (1999). Gene therapy: adenovirus-mediated human bone morphogenetic protein-2 gene transfer induces mesenchymal progenitor cell proliferation and differentiation in vitro and bone formation in vivo. J ournal of Orthopaedic Research, 17: 43-50. 